\title{
THE EFFECT OF SOCIODEMOGRAPHIC FACTORS ON THE PATIENT SATISFACTION WITH HEALTH CARE SYSTEM
}

Ivana Mitrovic Djordjevic ${ }^{1}$ and Dragan Vasiljevic ${ }^{2,3}$

${ }^{1}$ Primary school Dusan Dugalic, Belgrade, Serbia

${ }^{2}$ Faculty of Medical Sciences, University of Kragujevac, Kragujevac, Serbia

${ }^{3}$ Institute for Public Health Kragujevac, Kragujevac, Serbia

\author{
UTICAJ SOCIODEMOGRAFSKIH FAKTORA \\ O ZADOVOLJST VU PACIJENTA SISTEMOM ZDRAVSTVENE ZAŠTITE \\ Ivana Mitrović Đorđević1 i Dragan Vasiljević ${ }^{2,3}$ \\ ${ }^{1}$ Osnovna škola Dušan Dugalić, Beograd, Srbija \\ ${ }^{2}$ Fakultet medicinskih nauka, Univerzitet u Kragujevcu, Kragujevac, Srbija \\ ${ }^{3}$ Institut za javno zdravlje Kragujevac, Kragujevac, Srbija
}

\begin{abstract}
The goal of this paper is to determine the level of patient satisfaction with health care among adults in the Republic of Serbia and to analyze the correlation between the satisfaction and socio-demographic characteristics of the interviewees. The paper is based on the data provided by the National health survey of the Republic of Serbia. For the purposes of this paper, we used data on age and household of the people aged 19 and more. By eliminating the interviewees who were neither satisfied nor dissatisfied with the health care services, we obtained the sample containing 18.206 interviewees. Demographic characteristics and well-being index represented independent variables in the research. Dependent variable of the patient satisfaction was transformed into a binary variable by categorizing satisfied and very satisfied interviewees into one group and by placing dissatisfied and very dissatisfied interviewees into group of dissatisfied patients. The connection between satisfaction and predictors was examined using Chi-Square test and logistic regression. The percentage of the satisfied patients with health care was $72.9 \%$. The satisfaction level was directly connected to age, gender, marital status, employment, region the interviewee comes from and well-being index. Patients who were more satisfied included older people, women, as well as married people, the unemployed and those living in the cities. The analysis of the financial situation shows that the poorest interviewees were the most satisfied with health care.
\end{abstract}

Keywords: health care, patient satisfaction, socio-demographic characteristics

\section{SAŽETAK}

Cilj ovog rada je da se utvrdi stepen zadovoljstva pacijenata sa zdravstvenom zaštitom medu odraslima u Republici Srbiji i da se analizira korelacija izmedu zadovoljstva i socio-demografskih karakteristika ispitanika. Rad je zasnovan na podacima Nacionalnog zdravstvenog istraživanja Republike Srbije. Za potrebe ovog rada koristili smo podatke o starosti i domaćinstvu ljudi starijih od 19 godina. Eliminacijom ispitanika koji nisu bili zadovoljni niti nezadovoljni zdravstvenim uslugama, dobili smo uzorak sa 18. 206 ispitanika. Demografske karakteristike $i$ indeks blagostanja predstavljaju nezavisne varijable $u$ istraživanju. Zavisna varijabla zadovoljstva pacijenta pretvorena je u binarnu varijablu kategorizacijom zadovoljnih $i$ veoma zadovoljnih ispitanika u jednu grupu i postavljanjem nezadovoljnih $i$ veoma nezadovoljnih ispitanika u grupu nezadovoljnih pacijenata. Veza izmedu zadovoljstva $i$ prediktora ispitana je korišćenjem testa Chi-Skuare $i$ logističke regresije. Procenat zadovoljnih pacijenata sa zdravstvenom zaštitom iznosio je 72,9\%. Nivo zadovoljstva bio je direktno povezan sa starošću, polom, bračnim statusom, zaposlenjem, regionom od kojeg ispitanik dolazi i indeksom blagostanja. Pacijenti koji su bili zadovoljniji uključivali su starije ljude, žene, kao i venčane, nezaposlene $i$ one koji žive u gradovima. Analiza finansijske situacije pokazuje da su najsiromašniji ispitanici bili najviše zadovoljni zdravstvenom zaštitom.

Ključne reči: $z$ dravstvena zaštita, zadovoljstvo pacijenta, socio-demografske karakteristike
Corresponding author: Ivana Mitrovic Djordjevic Primary school Dusan Dugalic, Djerdapska 19,
11000 Belgrade, Serbia Primary school Dusan Dugalic, Djerdapska 19,
11000 Belgrade, Serbia Tel: +381 652205630 ; Fax: + 38134331344
E-mail: ikamitrovicdjordjevic@gmail.com; 


\section{INTRODUCTION}

Health care represents an organized and wide activity within one society which has a goal to protect and improve the heath of people. Making an available and comprehensive health care system represents a major challenge for every country (1). The old, but quite comprehensive divison of the health care model into Bismarck's, Siemaszko's and Beveridge's models has been abandoned resulting in mixed models in many countries, containing elements of the two or even all three models. Unsustainability of Bismarck's model in Serbia has forced the health policy creators to start a reform of the health care system during the 1990s. The reform included both financial and organizational changes (2).

The quality of health care, according to the definition by the World Health Organization, reflects the level of achieved goals of the health care system aimed at protecting and improving the health of people (3). Improving the quality of health care is conducted in three steps. First step includes defining the quality itself, the second includes defining the assessment indicators of it and the third includes designing of the improvement program (4). The biggest contribution to the process of defining indicators for the quality assessment of the given services was given by Avedis Donabedian. According to him, three major components which define the quality of health care are: structure, process and the result (5). The structure requires human resources, technical resources and clinical working guidelines. The process includes the percentage of patients who received the necesarry and, at the time, the best treatment in relation to the total number of patients (e.g. the percetange of patients with myocardial infarction who received thrombolytic therapy). The result is connected to the type of the disease and it includes the following: mortality and morbidity rate, functional and working status, the quality of life and patient satisfaction with the given health care service (6).

Subjective quality assessment of the given health care services mostly uses the following two indicators: patient satisfaction with health care and self-assessment of the health condition (7). Patient satisfaction with health care is reflected in a general and optimal quality of the given service which meets the needs of patients at the given moment (8). The level of patient satisfaction with health care services is used in the analysis of the health care reforms in a certain country as well as for comparison between different countries. Therefore, the World Health Organization, in cooperation with the Organization for Economic Cooperation and Development (OECD) started a project in 2002 in order to improve the quality of the given services across many countries around the world (9).

\section{THE GOAL OF THE PAPER}

The aim of this paper is to conduct an analysis of the sociodemographic factors and their effect on the patient satisfaction with the given health care services.

\section{MATERIAL AND METHODS}

The retrospective study which represents the part of the National research of public health in the Republic of Serbia was conducted in 2013 and funded by the Serbian Ministry of Health. The research was conducted as a crossstudy research and the obtained sample was a stratified two-phase sample, without repetition. The stratification was conducted in such a way that all 4 geographical areas (Vojvodina, Belgrade, Sumadija and West Serbia, South and East Serbia) represented one and the main stratum in the sample. Following that, each stratum was divided into cities and other regions. The total number of strata was 8 . Two-phase sampling includes municipalities as the units of the first phase and households as the units of the second phase. The questions and indicators in the questionnaires were standardized according to the questions used in EU, while the indicators are included in the database "Health for all" in World Health Organization.

In order to meet the requirements of the research, adult population aged 19 and more was analyzed (excluding Kosovo and Metohija). Dependent variable of the patient satisfaction, measured using Likert-type scale, was transformed into binary variable in the following way: the interviewees who were very satisfied or satisfied were categorized into the group of the satisfied patients and the interviewees who were dissatisfied or very dissatisfied were categorized into the group of patients who were dissatisfied with health care system. The interviewees who weren't either satisfied or dissatisfied were eliminated from the research.

\section{STATISTIC METHODS}

The data were described using descriptive statistical methods and analyzed using univariate or multivariate techniques of data analysis. The descriptive statistical method which was used was the patient ratio with the certain outcome. $x^{2}$ test was used to test the significance of the differences in frequency, using contingency tables. The correlation of the dependent variables with independent predicators was studied using logistic regression. The risk was estimated using OR value (odds ratio), with $95 \%$ of confidence interval.

The results are shown in tables. The results show the values (p) and the more important values are those which are $\mathrm{p} \leq 0.05$.

The data will be processed in SPSS (Statistical Package for the Social Sciences) 19.0 program.

\section{RESULTS}

The average age of the interviewees was $50.49 \pm 17.59$. Patients who were satisfied were 4 years older on average $(53.13 \pm 17.75$, as opposed to $49.38 \pm 16.52, \mathrm{p}<0.001)$. Gen- 
der analysis shows that women are more satisfied. Two thirds of married people and one third of those who are not married were satisfied with health care, $69.4 \%$ of the unemployed and $30.6 \%$ of the employed were satisfied with health care. The region analysis shows that the inhabitants of Sumadija and West Serbia are satisfied the most while people living in Vojvodina are the least satisfied, namely, every third person is dissatisfied with health care. People who live in cities are more satisfied that those who don't and half of the total number of interviewees graduated from high school. The analysis of the financial situation of the patients' households, measured using well-being index shows that the richest people are the least satisfied and the poorest are satisfied the most (Table 1).

The results of the binary logistic regression show that there is a statistically significant correlation between the patient satisfaction with health care and variables such as age, gender, marital or working status, region or financial situation of the interviewee.
Patient satisfaction reduces with age. Men are almost 1.2 times less satisfied with health care in comparison to women, and the same situation repeats with married and employed people. The region analysis shows that the interviewees coming from Vojvodina and Belgrade are 1.5 and 1.2 times less satisfied with health care respectively in comparison to people coming from South and East Serbia. The richest interviewees are 1.3 times less satisfied with health care in comparison to the poorest members of our society (Table 2).

\section{DISCUSSION}

Patients' experience and satisfaction represents an important indicator of the quality of the provided services (10). Based on that, one can notice and define the problems and realize which areas could be improved (11). The researches show that patient satisfaction influences the amount of hos-

Table 1. Satisfaction and sociodemographic characteristics of patients, univariate analysis

\begin{tabular}{|c|c|c|c|c|c|}
\hline \multirow[b]{2}{*}{ Variable } & \multicolumn{2}{|c|}{ Satisfaction } & \multirow{2}{*}{$\begin{array}{c}\text { Total } \\
\mathrm{n}\end{array}$} & \multirow[b]{2}{*}{$x^{2}$} & \multirow[b]{2}{*}{$\mathrm{p}$} \\
\hline & $\begin{array}{c}\text { Satisfacted } \\
\text { n (\%) }\end{array}$ & $\begin{array}{c}\text { Unsatisfacted } \\
\text { n (\%) }\end{array}$ & & & \\
\hline \multicolumn{6}{|l|}{ Gentle } \\
\hline Men & $5715(43.1)$ & $2358(47.8)$ & 8073 & \multirow{2}{*}{32.59} & \multirow{2}{*}{$<0.001$} \\
\hline Women & 7558 (56.9) & $2575(52.2)$ & 10133 & & \\
\hline \multicolumn{6}{|l|}{ Marital status } \\
\hline Married & 8829 (66.6) & 3374 (68.5) & 12203 & \multirow{2}{*}{5.27} & \multirow{2}{*}{$<0.05$} \\
\hline Other & $4420(33.4)$ & 1555 (31.5) & 5975 & & \\
\hline \multicolumn{6}{|l|}{ Employment } \\
\hline Employed & $4054(30.6)$ & $1879(38.1)$ & 5933 & \multirow{2}{*}{92.71} & \multirow{2}{*}{$<0.001$} \\
\hline Unemployed & 9213 (69.4) & 3053 (61.9) & 12266 & & \\
\hline \multicolumn{6}{|l|}{ Region } \\
\hline Vojvodina & 2938 (22.1) & $1484(30.1)$ & 4422 & \multirow{4}{*}{229.7} & \multirow{4}{*}{$<0.001$} \\
\hline Belgrad & 2458 (18.5) & $1112(22.5)$ & 3570 & & \\
\hline $\begin{array}{l}\text { Sumadija and } \\
\text { West Serbia }\end{array}$ & $4538(34.2)$ & $1236(25.1)$ & 5774 & & \\
\hline $\begin{array}{l}\text { Southern and } \\
\text { Eastern Serbia }\end{array}$ & 3339 (25.2) & $1101(22.3)$ & 4440 & & \\
\hline \multicolumn{6}{|l|}{ Residence } \\
\hline Urban & $7040(53)$ & 2793 (56.6) & 9833 & \multirow{2}{*}{18.4} & \multirow{2}{*}{$<0.001$} \\
\hline Rural & $6233(47)$ & $2140(43.4)$ & 8373 & & \\
\hline \multicolumn{6}{|l|}{ Education } \\
\hline Elementary & $4919(37.1)$ & $1511(30.6)$ & 6430 & \multirow{3}{*}{74.79} & \multirow{3}{*}{$<0.001$} \\
\hline Second & $6527(49.2)$ & 2585 (52.4) & 9112 & & \\
\hline High & $1827(13.8)$ & $837(17)$ & 2664 & & \\
\hline \multicolumn{6}{|c|}{ Well-being index } \\
\hline Poor & 3106 (23.4) & $946(19.2)$ & 4052 & \multirow{5}{*}{88.68} & \multirow{5}{*}{$<0.001$} \\
\hline Second & $2872(21.6)$ & $1062(21.5)$ & 3934 & & \\
\hline Third & $2826(21.3)$ & $960(19.5)$ & 3786 & & \\
\hline Fourth & $2430(18.3)$ & $968(19.6)$ & 3398 & & \\
\hline Rich & $2039(15.4)$ & $997(20.2)$ & 3036 & & \\
\hline
\end{tabular}




\begin{tabular}{|c|c|c|c|}
\hline Variable & Values & OR $(95 \% \mathrm{CI})$ & $\mathrm{p}$ \\
\hline Age & & $0.989(0.986-0.991)$ & $<0.001$ \\
\hline \multicolumn{4}{|l|}{ Gentle } \\
\hline & Women & 1 & \\
\hline & Men & $1.197(1.118-1.281)$ & $<0.001$ \\
\hline \multicolumn{4}{|c|}{ Education } \\
\hline & Elementary & 1 & \\
\hline & Second & $0.945(0.866-1.032)$ & $>0.05$ \\
\hline & High & $1.067(0.947-1.201)$ & $>0.05$ \\
\hline \multicolumn{4}{|c|}{ Marital status } \\
\hline & Other & 1 & \\
\hline & Married & $1.105(1.028-1.189)$ & $<0.05$ \\
\hline \multicolumn{4}{|c|}{ Employment } \\
\hline & Unemployed & 1 & \\
\hline & Employed & $1.087(1.004-1.176)$ & $<0.05$ \\
\hline \multicolumn{4}{|l|}{ Region } \\
\hline & Southern and Eastern Serbia & 1 & \\
\hline & Vojvodina & $1.536(1.399-1.686)$ & $<0.001$ \\
\hline & Beograd & $1.255(1.128-1.395)$ & $<0.001$ \\
\hline & Sumadija and West Serbia & $0.816(0.743-0.896)$ & $<0.001$ \\
\hline \multicolumn{4}{|c|}{ Residence } \\
\hline & Urban & 1 & \\
\hline & Rural & $1.030(0.951-1.116)$ & $>0.05$ \\
\hline \multicolumn{4}{|c|}{ Well-being index } \\
\hline & Poor & 1 & \\
\hline & Second & $1.144(1.030-1.272)$ & $<0.05$ \\
\hline & Third & $1.036(0.926-1.160)$ & $>0.05$ \\
\hline & Fourth & $1.154(1.021-1.305)$ & $<0.05$ \\
\hline & Rich & $1.313(1.145-1.507)$ & $<0.001$ \\
\hline
\end{tabular}

pital days, the results of the treatments and the degree of doctors' mistakes and it is one of the indicators of the successful work performed by doctors and medical institutions $(12,13)$. Patient satisfaction with health care is extensively used while analyzing reforms of the health care system all around Europe, Asia and America $(14,15)$.

The comparison of patient satisfaction among 4000 interviewees from Great Britain and USA shows that there is a significant difference between these two countries as well as between the regions themselves within one country.

The reform analysis of the health care system in China clearly shows the rise of patient satisfaction with health care among the interviewees coming from rural places following the reforms of the health care system.

The influence of age and gender factors on the satisfaction level varies. Some researches show that the older the patients are, the more satisfied they are (16-18) while some other researches deny the correlation between age and the level of satisfaction $(19,20)$. Some researches argue that men are more satisfied whereas some argue the opposite (21-23), while marital status generally does not affect the level of patient satisfaction (24). However, patient satisfaction is affected by a well-being index. Namely, patients whose financial situation is poor and those who are less educated are more satisfied with health care than those with better financial conditions $(25,26)$.

Communication between medical personnel and patients, along with socio-demographic factors, greatly influences the level of patient satisfaction with health care. The level of trust in the chosen doctor is directly correlated with the successful communication, especially among women and highly educated patients. So, by providing patients with detailed information about their condition prior to surgery, not only the patient satisfaction increases but the frequency of postsurgical complications reduces and the length of stay in the hospital decreases.

\section{CONCLUSION}

Analysis of the impact of socio-demographic characteristics of respondents to the satisfaction of health care is the way to better evaluate and understand the expectations of patients. Socio-demographic characteristics of the users of health care services significantly affect the satisfaction 
of health care. These facts health policy makers and health care providers should take into account when analyzing the health services.

\section{ACKNOWLEDGMENTS}

The study is a part of the 2013 National Health Survey for the population of Serbia (excluding Kosovo) that was carried out by the Ministry of Health of the Republic of Serbia with the professional support of the Institute of Public Health of Serbia „Dr Milan Jovanovic Batut“.

\section{REFERENCES}

1. Kert S, Švab I, Sever M, Makivić I and Rotar Pavlič D. A cross-sectional study of socio-demographic factors associated with patient access to primary care in Slovenia. International Journal for Equity in Health. 2015; 14: 39. DOI: 10.1186/s12939-015-0166-y

2. Jovanović S, Milovanović S, Mandić J, Jovović S. Sistemi zdravstvene zaštite. Engrami 2015; 1: 1.

3. Legido-Quigley H, McKee M, Nolte E and Glinos IA. Assuring the quality of health care in the European Union - A case for action. WHO - On behalf of the European Observatory on Health Systems and Policies; 2008: 2.

4. Pencheon D, Guest C, Melzer D, Muir Gray JA. Oxford Handbook of Public Health Practice. Second edition. Oxford: Oxford University Press, 2006.

5. Ayanian JZ and Markel H. Donabedian's Lasting Framework for Health Care Quality. N Engl J Med. 2016; 21: 375(3): 205-207. DOI: 10.1056/NEJMp1605101

6. Mainz J. Defining and classifying clinical indicators for quality improvement. Int J Qual Health Care. 2003; 15(6): 523-530.

7. Al-Abri R and Al-Balushi A. Patient Satisfaction Survey as a Tool Towards Quality Improvement. Oman Med. 2014; 29(1): 3-7. DOI: 10.5001/omj.2014.02

8. The Institute of public health of Serbia "Dr Milan Jovanović Batut". Results of the national health survey of the republic of serbia 2013. Belgrade: Ministry of Health, Republic of Serbia, 2014. Avaiable on: http:// www.batut.org.rs/download/izvestaji/Zadovoljstvo\%20 korisnika\%20ZZ\%202013

9. Data for Measuring Health Care Quality and Outcomes. Health at a Glance 2015 OECD Indicators. France: The Organisation for Economic Co-operation and Development (OECD), 2016. Avaiable on: http:// www.oecd.org > ... > Health policies and data

10. Saila T, Mattila E, Kaila M, Aalto P, Kaunonen M. Measuring patient assessments of the quality of outpatient care: A systematic review. J Eval Clin Pract 2008; 14: 148 -154.

11. Bradley EH, Holmboe ES, Mattera JA, Roumanis SA, Radford MJ, Krumholz HM. Data feedback efforts in quality improvement: Lessons learned from US hospitals. Qual Saf Health Care 2004; 13: 26-31.
12. Prakash B. Patient Satisfaction. J Cutan Aesthet Surg. 2010; 3(3): 151-155. DOI: 10.4103/0974-2077.74491

13. Shirley ED, Sanders JO. Patient Satisfaction: Implications and Predictors of Success. J Bone Joint Surg Am. 2013; 15: 95 (10): 69.

14. Gupta D, Patel K, Lis CG. Self-rated health supersedes patient satisfaction with service quality as a predictor of survival in prostate cancer. Health and Quality of Life Outcomes 2015; 13: 137. DOI: 10.1186/s12955-015-0334-1.

15. Rechel B, Ahmedov M, Akkazieva B, Katsaga A, Khodjamurodov G, McKee M. Lessons from two decades of health reform in Central Asia. Health Policy Plan. 2012; 27(4): 281-287. DOI: 10.1093/heapol/czr040.

16. Quintana JM, González N, Bilbao A, Aizpuru F, Escobar A, Esteban C. Predictors of patient satisfaction with hospital health care. MC Health Services Research 2006; 6:102. DOI: 10.1186/1472-6963-6-102.

17. Hargraves JL, Wilson IB, Zaslavsky A, James C, Walker JD, Rogers G et al. Adjusting for patient characteristics when analyzing reports from patients about hospital care. Med Care. 2001; 39: 635-641.

18. Jaipaul CK, Rosenthal GE. Are older patients more satisfied with hospital care than younger patients? J Gen Intern Med. 2003; 18: 23-30.

19. Hall JA, Dornan MC. Meta analysis of satisfaction with medical care: Description of research domain and analysis of overall satisfaction levels. Soc Sci Med. 1988; 27: 637-644.

20. Ziaei H, Katibeh M, Eskandari A, Mirzadeh M, Rabbanikhah Z, Javadi MA. Determinants of patient satisfaction with ophthalmic services. BMC Res Notes 2011; 4:7.

21. Wright SM, Craig T, Campbell S, Schaefer J, Humble C. Patient satisfaction of female and male users of veterans health administration services. J Gen Intern Med. 2006; 21(3): 26-32.

22. Abolfotouh MA, Al-Assiri MH, Alshahrani RT, Almutairi ZM, Hijazi RA, Alaskar AS. Predictors of patient satisfaction in an emergency care centre in central Saudi Arabia: a prospective study. Emerg Med J. 2016 DOI: 10.1136/emermed-2015-204954

23. Cleary PD. Adjusting for patient characteristics when analyzing reports from patients about hospital care. Med Care 2001; 39: 635-641. DOI:10.1097/00005650200106000-00011

24. Chen H, Li M, Wang J, Xue C, Ding T, Nong X et al. Factors influencing inpatients' satisfaction with hospitalization service in public hospitals in Shanghai, People's Republic of China. Patient Prefer Adherence 2016; 4(10): 469-477. DOI: 10.2147/PPA.S98095.

25. Afzal M, Rizvi F, Azad AH, Rajput AM, Khan A, Tariq N. Effect of demographic characteristics on patient's satisfaction with health care facility. J Postgrad Med Inst. 2014; 28(2): 154-160.

26. Dierssen-Sotos T, Rodríguez-Cundín P, Robles-García M, Brugos-Llamazares V, Gómez-Acebo I, Llorca J. Factors associated with patient satisfaction with hospital care. An Sist Sanit Navar. 2009; 32: 317-325. 